\title{
Openwork scheduling for steep-grade iron-ore deposits with the help of near-vertical layers
}

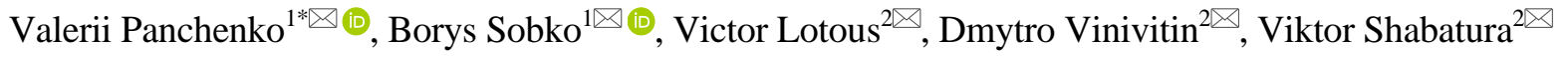 \\ ${ }^{1}$ Dnipro University of Technology, Dnipro, 49005, Ukraine \\ ${ }^{2}$ Ferrexpo Poltava Mining, Horishni Plavni, 39802, Ukraine \\ *Corresponding author: e-mail vpanchenko@nmu.org.ua, tel. +380980173834
}

\begin{abstract}
Purpose is to develop efficient scheduling to excavate steep-grade iron-ore deposits using near-vertical layers relying upon production practices by an open pit of Poltava Mining-and-Processing Integrated Works (MPIW).

Methods. The goal achievement involved system analysis of openwork scheduling for steep-grade iron-ore deposits by means of near-vertical layers in an open pit of Poltava MPIW; the scheduling process was structured from the viewpoint of decision-making under uncertainty.

Findings. New scheduling methods to excavate steep-grade iron-ore deposits by means of near-vertical layers have been developed. The methods have been represented in the informal (descriptive) structure being mandatory for further transition to formalization of certain stages of technological decision-making during scheduling. To improve the scheduling efficiency, it is recommended to prepare initial process data using K-MINE software; Deswik software is recommended to determine economic indices as well as pit outlines.
\end{abstract}

Originality. For the first time ever, a new mechanism of expedient spatiotemporal control of the specific excavation volumes while varying both "starting" time and intensity of a layer mining has been identified for the traditional openwork. The mechanism makes it possible to implement piecewise stable dynamics of annual output. Moreover, it also helps solve inverse problem, i.e. determine target values of spatiotemporal controlled parameters (i.e. "starting" time and intensity of the layer mining) for the required dynamics of ore and overburden excavation amounts.

Practical implications. The proposed methods concerning scheduling steep-grade iron-ore deposit mining using nearvertical layers relying upon production practices by an open pit of Poltava MPIW have been tested successfully. Their efficiency has been proved. Currently, they are the key procedures being applied to schedule extraction using near-vertical layers in the context of the considered open pit.

Keywords: iron-ore deposits, openwork, steep-grade layers, scheduling

\section{Introduction}

\subsection{Analysis of scientific and research} developments in the problem domain

\subsubsection{Developing the ideal of steep-grade iron-ore deposit excavation}

It is common knowledge that along with iron-ore open pit cutting and its wall advance, the total length of a possible front exceeds that one being necessary to provide the design capacity. As a result, both in terms of a plan and depth such wall areas occur, within which excavation could not be performed for a time [1]-[4].

The period can be defined as a stage one of a mining schedule. Typical features of the stage are as follows: full- scale mining operations and increase in layer-by-layer (instantaneous) stripping ratio according to the open pit cutting.

Stage two of a mining schedule may involve a period until a pit perimeter surface achieves its design position. Characteristic features of the stage involve mining by means of local working areas and use of various modifications of methods to preserve certain pit walls both in terms of the plan and depth. Mining concentration within the local working areas has made it possible to reduce expenditures connected with formation, maintenance, and development of transport networks and power circuits for excavation and removal; to some extent, temporary preservation of certain wall sections in terms of the plan and depth helped control a value of the current overburden ratio. However, the approach resulted in extra cost of temporary and financial resources to 
preserve and depreserve pillar remnants while complicating maintenance of productive capacity of an open pit.

In addition to the two abovementioned features of a mining schedule, stage two involves one more attribute coinciding with that from stage one, i.e. increase in layer-by-layer (instantaneous) stripping ratio.

After a pit perimeter surface achieves its design position and according to the pit cutting, the layer-by-layer (instantaneous) stripping ratio drops to zero when design depth is attained (stage three of a mining schedule).

Hence, the majority of overburden is extracted during stage three. The fact stipulates the prime costs associated with stripping operations right during the period while shifting their retirement and profit-making.

Stage four, being the last one, is possible for open pit bottom without its wall flattening (if remaining ore reserves are available).

According to extraction and geometry analysis of openwork of steep-grade iron-ore deposits, such a distribution of expenditures for mining is the applied traditional rock mass extraction using horizontal layers (i.e. benched extraction). In this context, mine blocks are displaced horizontally; as for the highwalls, they displace at $12-15^{\circ}$ angles.

It is obvious, that in the context of the situation, solving a problem of large overburden volumes during stage two and the first half of stage three depends upon the increase in values of highwall angles up to the values of design depreciation angles, i.e. $40-44^{\circ}$. Practical use of the idea required innovative technology concept. The solution has been found in the transition from horizontal movement of mine sections, forming a lateral bench layer, to a steep-grade trajectory of a mine section movement, forming a near-vertical layer. Essentially, the solution implemented the idea of a trench method for underground heading-and-bench mining of lode deposits with hard rocks and heavy pitch [5] in the context of open-pit mining of steep inclined occurrences.

\subsubsection{Available conceptual proposals concerning the idea implementation and their theoretical studies}

In the early 1980s, Ukrainian specialists from Poltava Mining-and-Processing Integrated Works (MPIW), and the Department of Surface Mining of Dnipropetrovsk Mining Institute (DMI) first started activities aimed at implementation and scientific substantiation of openwork of steep-grade iron-ore deposits with the help of near-vertical layers.

Paper [6] was one of the first publications stated the key conceptual proposals concerning openwork of steep-grade iron-ore deposits with the help of near-vertical layers. Figure 1 explains the principal operation schedule.

As Figure 1 demonstrates, the operation schedule involves near-vertical movement of mine sections within benches rather than horizontal one. The fact is the vital difference.

To progress the basic conceptual proposals concerning implementation of open-pit mining using near-vertical layers, paper [7] has tried to solve a problem to determine dependences of an opencast efficiency upon cutting zone depth and area; number, length, and width of bear-vertical layers as well as height of temporarily inactive sites between them; and drawdown intensity of the overburden layers, and transfer interval of the reloading points. It was proposed to solve the problem relying upon the mining and geometric analysis of an open-pit operating space development down to the final depth based upon the proposed methods.

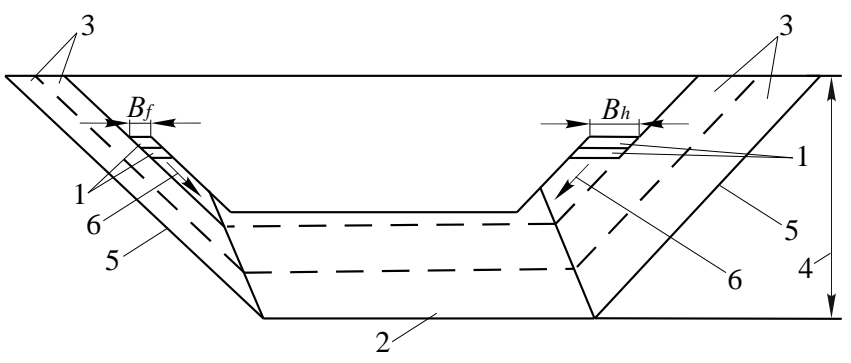

Figure 1. Principal operation schedule to excavate steep-grade deposit using near-vertical layers: 1 - horizontal mine sections; 2 -orebody; 3 -near-vertical layers; 4 -final depth; 5-final (i.e. design) location of pit walls; 6 -movement direction of horizontal mine sections; $B_{h}$-width of a horizontal mine section within the near-vertical layers of a hanging wall; $B_{f}-$ width of a horizontal mine section within the near-vertical layers of a footwall

However, the paper did not represent any of the methods in the form of a clear order to identify the dependences nor adequate calculations. The set of different formulas is only available without any procedure concerning their association.

The formulas have been proposed on the basis of the simplified traditional approach, i.e. the formalized figure of an opencast section with one steep-grade mineral layer in the form of a regular geometric object being a parallelogram. According to the initial figure, only overburden will be excavated with the help of near-vertical layers; the proposed formulas are correct for the figure merely.

It is obvious that currently determination of open pit efficiency in terms of the formulas is far from being expedient since geology of any opencast almost always differs from a conventional formalized figure; moreover, one section cannot represent all the factors determining the open pit efficiency.

Static nature of the proposed formulas (i.e. independence of the arguments as well as the opencast productive capacity from time); by comparison, the abovementioned parameters are dynamic values in practice.

Nevertheless, at that date the obtained results were of the undoubted interest (for instance, formation of near-vertical layers is quite rational thing if the deposit thickness is up to 200-250 m; width of the operating spaces should be $50 \mathrm{~m}$; height of temporary preservation sites is $90-12 \mathrm{~m}$; and depth of the transition to openwork using near-vertical layers is 210-240 m). Currently, they look like simplified ones; moreover, some of them turn out to be even doubtful since they cannot reflect possible ranges of values of process conditions of the steep-grade layers.

Paper [8] represents more complete statement of conceptual proposals to implement openwork using near-vertical layers with the development of a number of engineering solutions; among other things, it concerns excavation of near-vertical layers with the help of motor-vehicle transport.

Papers [9]-[11] are further continuation of [6]-[8] papers. No new concepts are involved in [9], [10] papers. Mostly, they popularized the new method of iron-ore deposit excavation with the help of near-vertical layers as well as its advantages. It should also be noted that a title of paper [10] mentions such a word combination as heading-and-bench method suppor-ting connection with [5] paper.

In addition to the formalized simplified figure of an open pit section, paper [11] represent stripping concept in the plan 
as well as the formalized simplified figure for one ore layer being of regular geometric object, i.e. rectangle.

The known idea of the initial opencast end excavation per its design depth with following overburden progress towards another end of the open pit is stated [12]-[14]. It is proposed to perform the development by means of diagonal stopes within several near-vertical layers on a lying wall as well as a hanging wall synchronously.

Like in each previous paper, ore extraction is not considered; moreover, it is supposed that near-vertical layer is applied for overburden merely. Hence, stripping-mining connection is ignored. Nevertheless, progress of the latter is of higher priority and stripping operations should be performed in terms of such areas, volumes, and terms providing the required sufficiency of the accessed reserves. Taking into consideration natural shape of ore bodies as well as usual availability of several types of ores, being of the varied preparability degrees, it is possible to say that the concept, proposed by paper [11], concerning the concept of progress of stripping operations as an independent planning object is non-constructive idea. Practices support that: first, mining operations are planned; stripping operations follow them in terms of areas, volumes, and terms providing the required reserve development.

The analyzed [6]-[11] papers can be considered as a stage one while developing the method of near-vertical layers. Conceptual nature of the papers is their common feature: they describe openwork of iron-ore deposits by means of near-vertical layers without any in-depth engineering study of the process solutions.

From the viewpoint of current scientific and research developments, following minuses of the papers, belonging to stage one, should be mentioned:

1) plane problems rather than spatial ones were solved on the simplified diagonal vertical and horizontal open pit sections; mineral deposit was assumed as that of regular geometric shape rather than actual natural one; near-vertical layers were arranged only along overburden; and stripping operations were considered as a planning object independent from mining operation planning;

2) different formulas were derived relying upon the listed initial conditions; dependences were identified; and recommendations were proposed as for the "rational" parameters of near-vertical layers. However, there are no practical supports of their approval since the simplified approach was applied (for instance, the formulas reflect only partial dependences of an open pit dependence upon certain facts in terms of the assumed simplifications. Thus, the efforts to make overall conclusions relying upon the formulas are incorrect ones);

3 ) in terms of the same reasons, the derived formulas are of static nature; hence, they cannot represent adequately the dynamics of near-vertical layer mining (values of the arguments are time independent).

Nevertheless, stage one of a process of a new scientific tendency development is usually connected with simplifications. It is quite important to test adequately its results as well as probable application area. In our case, explanation of idea and problem, connected with a partial valuation, are meant; for instant, it concerns a dependence of overburden volume upon width of operating space of a near-vertical layer.

Moreover, today operation results of stage one are used for raw estimation of operational parameters of near-vertical layers as well as different dependences while playing as an initial position to develop engineering solutions concerning different aspects of near-vertical layers in terms of iron-ore deposit openwork.

\subsubsection{Scientific developments of certain types of the related problems}

Particularity of the majority of following papers is a transition from conceptual proposals as for the iron-ore deposit excavation by means of near-vertical layers to engineering solutions concerning its implementation. The particularity helps determine them as stage two of the research.

Analysis of the papers, belonging to stage two, made it possible to single out following certain characteristic types of the problems being solved:

1) shaping and arranging of highwalls in their ultimate (i.e. design) position and evaluation of their stability [15]-[19];

2) arrangement of the near-vertical layers and transport communication matching with them [20];

3 ) complement of the powered systems to excavate the near-vertical layers [21], [22];

4) shaping of the open pit mined-out space [23].

These problems as well as similar ones have been generalized as chapters in numerous monographs and manuals [24]-[27].

The problems were solved based upon one and the same simplified grapho-analytical approach as in the activities of stage one. Hence, the abovementioned disadvantages of stage one take place in this context as well. However, smaller extent of the problems compared with the development of conceptual proposals, minor composition of determinative factors, and greater data reliability eased the disadvantages, and helped obtain engineering solutions for the specific conditions with the specific practical importance (e.g. papers [20]-[22] are meant).

Nevertheless, up to now the key purpose of the scientific tendency has been achieved since neither methodology nor methods to design and schedule the technique to excavate steep-grade iron-ore deposits using near-vertical layers have been developed. We believe it has happened due to the limited possibilities of the simplified grapho-analytical approach being applied.

\subsubsection{The developments}

Again, in the 1980s, a number of experimental sites were developed at Poltava MPIW to set a highwall to its design position using near-vertical layers. The development and test was based upon the actual calculations by engineers and technicians of the Integrated Works relying upon the parameters of the available facilities, available development of transport communications, data concerning the highwall stability, and other specific engineering solutions tested in the open pit. To assess intervals of rational values of technological parameters of near-vertical layers, experiments were carried out concerning length, width, and height of mine sections; operation schedules as for the transition to the extraction of underlying mine sections; junction of roads where rock mass is transported; and other important actions.

Currently, certain practical approaches and operation techniques of heuristic nature have already been developed and applied to schedule and extract such steep-grade iron ore deposits as Horishni Plavni and Lavrikovka with the help of near-vertical layers.

Distinctive features of the listed practical approaches and operation techniques are as follows: 
- specific problems as for the implementation of excavation of steep-grade iron-ore deposits using near-vertical layers were formulated and solved rather than tasks to obtain general theoretical results;

- initially, three-dimensional models of near-vertical layers were in a focus; currently, block mining and geological models are applied as well as GIS K-MINE tools;

- operation schedules are developed to extract specific near-vertical layers on the basis of the tested engineering solutions as well as generalization of industrial practices taking into consideration expert analysis of numerous factors providing more adequate and reliable solutions.

Hence, despite nonavailability of theoretical substantiation in many cases, the developments, intended to achieve specific results, turned out to be more constructive and progressive to compare with the simplified grapho-analytical approach.

However, there are no methodology and methods as a specific sequence for technological decision making (the matter is that such a task was not formulated). As it has been mentioned, open pit applies subjectively defined set of practical operational techniques to form alternatives for extraction of near-vertical layers, their empiric comparative analysis, and heuristic selection of an alternative accepted as a rational one. Nevertheless, despite the mentioned advantages, implementation of the practical approach is associated with ambiguousness of the obtained results. Anyway, certain positive operational experience has been accumulated and the necessity has become obvious to make following move towards further improvement to design and schedule deposit excavation using near-vertical layers. At the same time, currently the improvement is suppressed by the lack of adequate methods.

\subsection{Setting objectives of the paper and the problem defining}

In accordance with the abovementioned substantiation, the paper objective is to develop scheduling methods as for the excavation of steep-grade iron-ore deposits using nearvertical layers (hereinafter referred to as Methods...) based upon industrial practices of Poltava MPIW open pit.

Selection of scheduling from a hierarchic set of levels depends upon its central binding role between the design scheduling and the scheduling during operation period of an open pit.

The analysis of scientific sources as well as practices by Poltava MPIW open pit has made it possible to propose following formulation of problem description of scheduling for excavation of steep-grade deposit with the help of nearvertical layers: it is required to identify such year-wise sets of simultaneously excavated near-vertical layers to support necessary accessed reserves; moreover, unstable overburden coefficient should become stable for certain time periods.

\section{Identifying the problem type as well as methodology to perform the activities}

Also, analysis of industrial practices of Poltava MPIW open pit has shown that the complexity to develop scheduling methods depends upon the complexity of a scheduling problem itself due to its poor formalizability:

- numerous technological, economic, and subjective factors with ambiguous mechanism of influence;

- qualitative nature of vitals of the factors;

- probabilistic nature of the majority of the factors as well as probabilistic accuracy of their forecast;
- necessity of multicriteria assessment of the scheduling alternatives; however, in the majority of cases, the criteria priority is of ambiguous nature;

- dynamics of the problem;

- the key role of technical employees while making decisions in terms of formation of the schedule alternatives as well as in terms of rational schedule selection.

The abovementioned peculiarities of the problem refer it to a class of decision-making in the context of uncertainty conditions [28]. The problems, belonging to the class, involve two levels of their solution methods: informal (i.e. verbal) level and formal one.

In turn, formal representation includes structuring of the decision-making process to formulate the schedule alternation, and selection of the most rational one [29]. In this context, the structuring is singling out of discrete stages of the methods involving determination of their information and functional connections.

For this reason, the paper developed methods to solve the scheduling problem right in the informal (verbal) form.

The two basic methodological principles were applied for the considered methods to excavate steep-grade deposits by means of near-vertical layers:

- spatial modeling of the steep-grade seam extraction rather than geometrical formulas for two-dimensional open pits;

- the required year-to-year extraction amounts were not determined in terms of separate near-vertical layers but in terms of their probable spatial unions (i.e. sets, superimpositions) in the context of their spatiotemporal and technological interrelation.

\section{Development of scheduling methods for openwork of steep-grade iron-ore deposits with the help of near-vertical layers}

As the assumed methodology has involved, the developed methods are structuring of informal scheduling level based upon current practical approaches and processes with subjectivity elements being typical for decision-making under uncertainty conditions.

\subsection{Stage of the analysis of current production situation and initial data preparation}

Since the paper considers scheduling at the stage of an open pit operation, the set of initial data for the methods should also involve information concerning current production situation of the open pit. Composition of the data as well as their consideration procedure is performed by a production engineer (i.e. decision maker, DM).

\subsubsection{Example of typical production satiation in Poltava MPIW open pit}

According to mining and geological conditions, cutting mining system is applied with the use of near-vertical layers. The open pit is of a prolate shape; two main walls (i.e. western and eastern) are working ones. Cutting speed depends upon productive ore capacity of the open pit; it is 10-20 m/year.

Superficially, open-pit field periphery is broken down into sites in terms of both highwalls (i.e. near-vertical layers to be extracted) with 1500-2000 m front length and 50-150 m width of work area (Fig. 2).

The near-vertical layers, resulting from the cut, are mined with annual 20-70 m lowering of the work areas and temporary arrangement of the highwall zones at angles being close to final ones. 


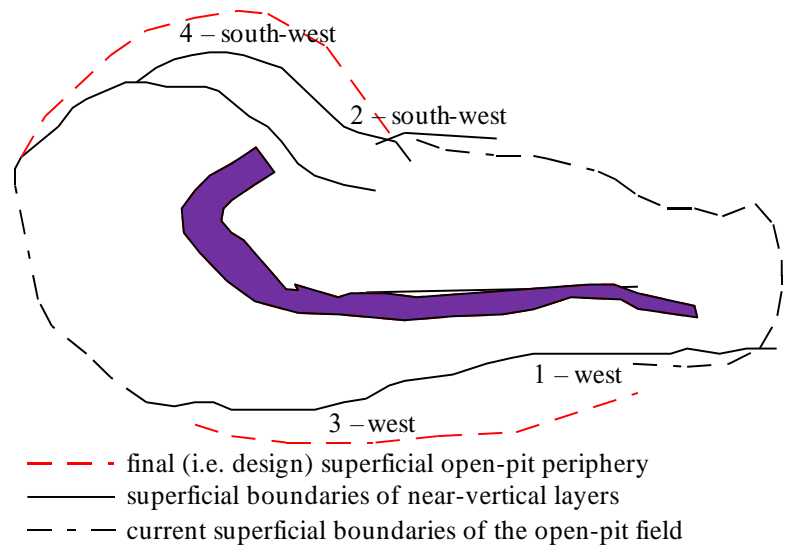

Figure 2. Open-pit field

Extraction of the near-vertical layers is represented with the help of dynamics of volumes of mine sections (the procedure has been involved by methodological condition one of the method development).

Depending upon the required ore production capacity of the open pit, several layers are extracted simultaneously. The layers are at different extraction stages, i.e. it may be openwork, stripping operations or development.

In this context, the near-vertical layers, experiencing stripping operations, are at such a development stage to transfer to extraction activities when it is necessary to compensate disposal of mining capacities taking place owing to previous ore reserve openwork by means of forgoing layers (the procedure has been involved by methodological condition two of the method development).

The process of a near-vertical layer from the area of stripping operation transition to the area of extraction operations should have certain time reserve. Otherwise, failures are possible in the provision of the required ore volumes for the mining procedure or the increased amounts of stripping operations. Near-vertical layers are extracted basing upon the schedule.

\subsubsection{Data origination within the K-MINE software system}

The K-MINE software system is the basic means for data origination and manipulation.

Step one develops mining and geometrical model of an open pit (actual position of bench edges is given both for near-vertical layers and for the open pit on the whole). After the planning, the mining and geometrical model is added by a planimetric position bench edges in terms of near-vertical layers and in terms of the open pit on the whole. The KMINE tools make it possible to work with the models both separately and in superposition.

Following stage is a block geological deposit model upload into the K-MINE software system. Then, the model is superimposed on the mining and geometrical model. The KMINE tools for the superimposed model help calculate amounts in terms of rock and ore types, ore grade, levels, mine sections of near-vertical layers etc.

\subsubsection{Data origination in the context of the Deswik software system}

Scheduling involves knowledge of feasible final (i.e. design) open pit periphery. For the purpose, the Deswik soft- ware system is recommended; the following can be considered as source data for it:

- block geological deposit model;

- such economic indices as expenditures connected with the whole technological cycle to manufacture the end product; market price for certain grade pellets etc;

- safe parameters of the open pit walls (depth, inclination angle) etc.

\subsubsection{Open pit field cutting in near-vertical layers}

As it has been mentioned, data origination also includes cutting of open pit areas (i.e. work areas) in the near-vertical layers between the available or design position of a stage periphery and final (i.e. specified) open pit periphery. The cutting is possible if only working area width is more than $250 \mathrm{~m}$.

The abovementioned cutting of working areas of the open pit in the near-vertical layers should involve following technological factors:

- lateral length of a near-vertical layer has to provide the required front for excavators; generally, it is $1000-3500 \mathrm{~m}$;

- width of a near-vertical layer has to provide equipment arrangement in compliance with the safety requirements assumed as 60-250 m; narrower near-vertical layer will stipulate increase in mutual idle time of mining and loading as well as drilling facilities (being $20-30 \%$ for excavators); near-vertical layer widening will result in rather significant increase of annual amount of stripping operations factoring into the increased current overburden ratio;

- determination of a near-vertical width and length should also involve opening scheme (i.e. transport accessibility); in this connection, boundaries of the near-vertical layers are linked with the available mine openings.

In the context of each near-vertical layer, a project is developed concerning its final position after extraction is over; amounts of ore, being extracted, as well as overburden are calculated from year to year and/or in terms of levels if a work area is lowered; moreover, the calculations concern all rock types (as for the methods, the calculations are performed using the K-MINE software system).

\subsection{Determining the priority to excavate certain near-vertical layers}

Determination of the priority as for certain near-vertical layers is of key importance while defining rational sequence for their set mining.

The factors, forming priority of a near-vertical layer, are as follows:

- closeness of spatial location of the near-vertical layer to the main direction of mining schedule (layers within the main directions will be of high priority);

- compliance degree of planimetric position periphery of a near-vertical layer with the current schedule (layers with the greatest lag will be considered as the priority ones);

- close (neighbouring) spatial location of a near-vertical layer relative to other ones making it possible to concentrate extraction operations for the shared use of transport communications and power utilities (the layers, forming common work area, will be considered as the priority ones);

- expenditures connected with construction, development, and maintenance of transport communications and power utilities (the layers with the least expenditures will be considered as the priority ones); 
- spatial location of a near-vertical layer relative to the permanent open pit walls (the layers, which extraction will involve formation of a spoil-pile wall in the permanent position; later, it will be used to arrange transport communications);

- spatial location of a near-vertical layer relative to current position of mine sections of the layers being mined;

- mining amount as for the mineral opening (the layers with minimum amounts will be considered as the priority ones);

- miming performance time as for the mineral opening (the layers with minimum time will be considered as the priority ones);

- mineral reserves in terms of final boundary of a nearvertical layer (the layers with maximum reserves will be considered as the priority ones);

- possibility to use the mined-out area in future to arrange inside dump when extraction of the near-vertical layer is over (the layers with comfortable possible arrangement of the inside dump will be considered as the priority ones).

Specific evaluations of the priorities are identified by expertise. The generalized priority of each near-vertical layer should involve significance of the abovementioned factors. In each specific situation, they are determined by expertise as well.

\subsection{Basic procedures and operations of the scheduling}

The methods implement the scheduling in terms of each near-vertical layer as well as in terms of general schedule of the open pit for the specified period of time.

The two basic procedures involve:

1) schedule formation in terms of ore with the required dynamics of annual output;

2) schedule formation in terms of overburden with stable or piecewise-stable dynamics of their annual output according to the calculated ore schedule.

In turn, procedure one includes two operations:

1.1) determination of the following near-vertical layer extraction start to support timely the required dynamics of the annual ore output;

1.2) smoothing of the developed ore schedule (if required).

Procedure two also includes two operations:

2.1) determination of the annual schedule output in terms of overburden according to the developed ore schedule;

2.2) smoothing of the overburden schedule to obtain stable or piecewise-stable dynamics of their annual output.

\subsection{Forming the ore schedule}

Schedule formation (procedure one) starts with the analysis of dynamics of the prescheduled mining amounts on the annual basis.

If ore amount is less than the scheduled one, then next best near-vertical layer is added; thus, its ore amount is also added. If ore amount is more than the scheduled one, then one of the layers, being the least preferable, is excluded from consideration. In such a way, a set of layers is selected to provide ore output targets.

When a period, after which one or another near-vertical layer is eliminated, is over, ore output starts its decrease. Hence, it is required to "launch" timely the following nearvertical layer to compensate the decreased output (1.1 operation). For the purpose, the layer mining start time is determined. After the selected near-vertical layer "launch", ore and burden extraction amounts are considered in the schedule on the annual basis.
Then, dynamics of the formed year-based ore output is analyzed again. Following near-vertical layer is "launched" at a certain moment. The cycles are performed during the whole schedule.

After the last near-vertical layer is "launched", the cycles terminate which corresponds to the final stage of the initial (the first one) alternative of ore schedule.

The abovementioned may involve fluctuations of annual ore output exceeding the admissible one. To decrease it, operation 1.2 is meant, i.e. smoothing (moderating) of the deviations:

- intensity variation of ore extraction in terms of one or another near-vertical layer both towards the increase and decrease (the ore is transported to a crushing and concentrating plant);

- increasing intensity variation of ore extraction in terms of one or another near-vertical layer; if the required amount is exceeded, then the ore is transported to a stockpile.

The smoothing technique is selected specifically in each individual case depending upon the predicted situation. Generally, use of their combinations is possible.

\subsection{Forming the overburden schedule}

As it has been mentioned, the overburden schedule is formed with no modifications of the formed ore schedule. An engineering requirement is to stabilize the current overburden ratio. If it is impossible to provide the stabilization during the whole scheduling period, then it remains possible to increase current overburden ratio for certain intervals of the scheduling period and stabilize it at each level (piecewisestable dynamics). Assembly of schedule amount in terms of stripping operations according to the determined ore schedule (operation 2.1) is performed synchronously with the determined ore assembly. If it turns out that significant deviations (fluctuations) of year-based overburden amount take place, they are smoothed down (operation 2.2).

To implement that, two smoothing techniques are proposed depending upon the extraction stage of a near-vertical layer: a stage before the ore access and a stage of ore and overburden excavation. Stage one recommends to apply operations 1.1 being similar to the operations with ore; however, time for ore obtaining is not varied since the achieved stability in terms of ore will be violated. Another technique is recommended for stage two when ore and overburden are extracted jointly. It is as follows: in terms of sharp and significant variations in overburden amounts towards increase, a transition the greater extraction level takes place owing to the "start" of near-vertical layers with larger initial overburden volumes. Since it is necessary to repay expenditures connected with extra mining and loading as well as transport facilities, the stage should be prolonged.

\subsection{Forming a set of alternatives and selecting a rational one of them}

To obtain rational alternative of the schedule (point 3 of the Methods), 1-2 of its versions are formed analogously; then, expert method is applied to select from the set that one to be accepted as a rational variant.

\section{Illustrating the methods implementation}

As it is known, the openwork schedule is always represented in the tabular and graphic forms.

In the context of traditional mining methods (when benches are displaced horizontally), tabular form of a sche-dule mentions excavation volumes in terms of years as well as in 
terms of rock mass types for each level and for the open pit on the whole. Moreover, if a deposit is mined using near-vertical layers, a tabular form also indicates the scheduled extraction amounts in terms of years as well as in terms of rock mass types for each near-vertical layer and for the whole open pit.

In the context of a graphical form, the amounts are represented generally within the layer-oriented and/or annul schedules involving their peripheries and location. Moreover, a schedule may be represented in the form of a graph showing annual amounts of the extracted rock mass as well as in terms of the whole open pit. If an open pit is mined using near-vertical layers, such graphs for each near-vertical layer may be represented additionally. Generally, Gantt chart is constructed for each near-vertical layer as for its extraction sequence and duration in terms of overburden and ore.

The increased number of forms concerning a schedule representation while a deposit mining by means of nearvertical layers depends upon the fact that certain share of them is used to analyze dynamics of the extracted amounts, and make the planned engineering decisions while forming annual volumes of ore and overburden extraction.

Below, you can find examples of graphic representation of such schedules (Figs. 3-5).

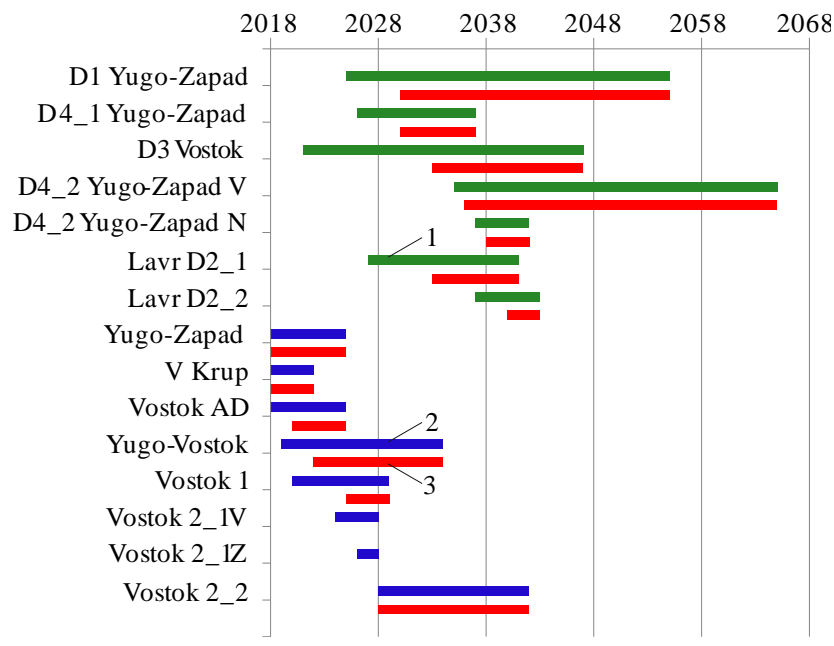

Figure 3. Example of a schedule to extract near-vertical layers (in the form of Gantt chart): 1 - time to mine the scheduled overburden amounts of near-vertical layers being extracted according to the previous schedule; 2 -time to mine the scheduled overburden amounts of nearvertical layers; 3 -time to mine ore within the nearvertical layers

Leftwards, Figure 3 demonstrates specifications of the near-vertical layers; horizontal sections to the left explain start time as well as duration of overburden and ore extraction from each layer.

Ore schedule formation will look in Figure 3 like documentation of positive layer graphs (green sections) according to the calculated time for their development start; in turn, smoothing of annual amounts of ore extraction (red sections) will look like lengthening or shortening of the red sections.

A procedure to form a schedule for overburden mining (i.e. calculation of its amount in step with ore amounts) will have no variations in Figure 3 (green sections). Smoothing of annual overburden extraction volumes will look like lengthening or shortening of the green sections in terms of the fixed location of red sections.
Figure 4 exemplifies schedule of ore, overburden, and rock mass extraction in the open pit (with no smoothing of overburden and ore amounts).

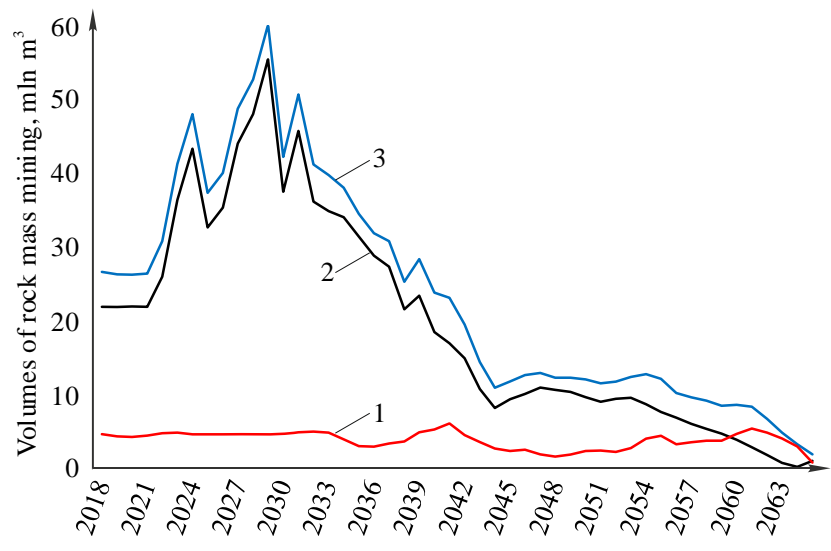

Figure 4. Example of an extraction schedule in the open pit: 1 -ore; 2 -overburden; 3 -rock mass (before ore and overburden amounts were smoothed down)

It is obvious that such a schedule alternative is not acceptable due to peak stripping operations during the first half of the scheduling period. Smoothing of the overburden amounts is required (see procedure 2 and operations 2.1, 2.2 of the Methods...). Moreover, it is also necessary to smooth down ore extraction amounts; however, their fluctuations are not so sharp.

Figure 5 demonstrates an example of the schedule variation after the overburden and ore amounts were smoothed down.

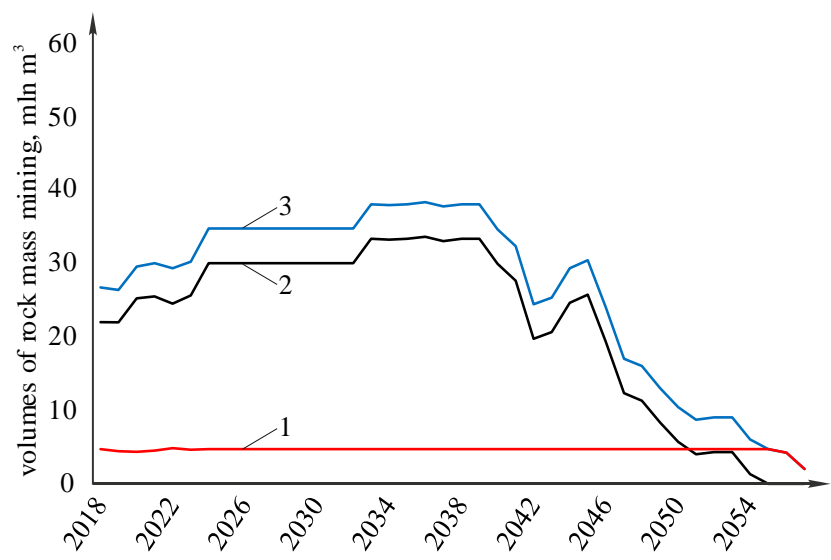

Figure 5. Example of extraction schedule in the open pit: 1 -ore; 2 -overburden; 3 - rock mass (after smoothing down)

Time intervals of piecewise dynamics of the overburden and rock mass amounts are clearly seen. Thus, illustration of the implementation supports obviously the performance capability and efficiency of the Methods...

\section{Conclusions}

1. Analysis of the unsystematic practical approaches to form alternatives for extraction of near-vertical layers, available at the integrated works, methods of their empiric comparative studies, and means of subjective heuristic selection of a variant, assumed as a rational one, openwork scheduling for steep-grade deposits using near-vertical layers has been classified as decision-making under uncertainty. 
According to a concept to solve such problems, two steps have been identified while developing the Methods... They are as follows: the decision-making process structuring (i.e. representation of the Methods... as a logically ordered set of procedures and operations described at an initial informal level) and the decision-making process formalizing to formulate the schedule variations and select rational one (i.e. representation of the Methods...as an ordered set of both mathematical and subjective models).

The paper has effectuated step one which implementation has supported identification correctness of the problem type as well as adequacy of the concept to develop the Methods...

2. The proposed procedures and operations to form and smooth down dynamics of ore and overburden amount extraction are original ones. Their originality is the determination of engineering mechanism of the targeted spatiotemporal control of specific excavation volumes while varying "start" time as well as intensity of a layer mining making it possible to implement piecewise-stable dynamics of annual extraction amounts. Inverse mechanism is also probable; it determines the required values of spatiotemporal controlled parameters (i.e. "start" time and intensity of a layer extraction) for the appropriate dynamics of ore and overburden volume mining. Such a mechanism could not be identified for traditional openwork methods.

3. Practical implications is in successful testing of the proposed Methods... while mining operations scheduling for Poltava MPIW and its efficiency supporting. Currently, they are the basic applied procedures providing scheduling of openwork in the open pit using near-vertical layers.

4. The paper represents the Methods... at an informal (descriptive) level being initial for further formalization stages of making engineering decisions in the process of nearvertical layer mining. The most complex decision-making stages (i.e. formation of the schedule alternatives and selection of a rational one) should be formalized. It is known that in the context of the problems such complete formalization is unreachable; however, even partial formalization creates prerequisites for the development of a system, supporting the decision-making process with the use of software tools which will decrease labour intensity, save time, and improve the scheduling efficiency for excavation of steep-grade deposits with the help of near-vertical layers.

\section{Acknowledgements}

The research was carried out under the Agreement on cooperation in the areas of science and technology between the Dnipro University of Technology and Poltava Miningand-Processing Integrated Works. The authors thank engineering staff of Poltava Mining-and-Processing Integrated Works for enthusiasm and pilot practical studies.

\section{References}

[1] Dryzhenko, A., Moldabayev, S., Shustov, A., Adamchuk, A., \& Sarybayev, N. (2017). Open pit mining technology of steeply dipping mineral occurences by steeply inclined sublayers. International Multidisciplinary Scientific GeoConference, (13), 599-606. https://doi.org/10.5593/sgem2017/13/s03.076

[2] Moldabayev, S., Adamchuk, A., Sarybayev, N., \& Shustov, A. (2019). Improvement of open cleaning-up schemes of border mineral reserves. International Multidisciplinary Scientific GeoConference, (19), 331338. https://doi.org/10.5593/sgem2019/1.3/s03.042

[3] Khomenko, O.E., Kononenko, M.N., \& Lyashenko, V.I. (2019). Safe mining of granites at the manganese ore deposits of Ukraine. Occupa- tional Safety in Industry, (1), 53-61. https://doi.org/10.24000/04092961-2019-1-53-61

[4] Kobelyatskiy, I.Y., Panchenko, V.V., \& Solodovnik, L.M. (2011). Optimization of the movement of transfer points on the horizons in the deep iron ore open pit. Metallurgical and Mining Industry, 3(5), 235-240.

[5] Matveev, N.I (1948). Nekotorye osobennosti pochvoustupnoy vyemki. Gornyy Zhurnal, (2), 3-5.

[6] Drizhenko, A.Yu., \& Bogdanov, V.M. (1987). Sposob otkrytoy razrabotki krutopadayushchikh mestorozhdeniy. Avtorskoe svidetelstvo 1303715 SSSR.

[7] Drizhenko, A.Yu., \& Bogdanov, V.M. (1988). Obosnovanie parametrov poetapnogo razvitiya glubokikh kar'yerov. Gornyy Zhurnal, (6), 46-50

[8] Bogdanov, V.M. (1989). Obosnovanie parametrov poetapnogo razvitiya glubokikh kar'yerov krutymi sloyami. PhD Thesis. Dnepr, Ukraina: Dnepropetrovskiy gornyy institute, $174 \mathrm{~s}$

[9] Drizhenko, A.Yu. (2004). Novye tekhnologicheskie resheniya po razrabotke glubokikh zhelezorudnykh kar'yerov etapami. Geotekhnologicheskie Problemy Kompleksnogo Osvoeniya Nedr, 2(92), 212-226.

[10] Drizhenko, A.Yu. (2008). Pochvoustupnaya vyemka porod vskryshi krutonaklonnymi sloyami pri otkrytoy razrabotke krutopadayushchikh zhelezorudnykh mestorozhdeniy. Geotekhnologicheskie Problemy Kompleksnogo Osvoeniya Nedr, 4(94), 96-101.

[11] Drizhenko, A.Yu. (2011). Etapnaya otrabotka vskryshnykh porod zhelezorudnykh kar'yerov krutonaklonnymi vyemochnymi sloyami. Gornyy Zhurnal, (2), 25-28.

[12] Stupnik, N., Kalinichenko, V., Kolosov, V., Pismennyy, S., \& Shepel A. (2014). Modeling of stopes in soft ores during ore mining. Metallurgical and Mining Industry, 6(3), 32-37.

[13] Pivnyak, G.G., Efremov, E.I., \& Gumenik, I.L. (2002). On the teaching book of K.N. Trubetskoi, G.L. Krasnyansky, V.V. Khronin. Designing of pits. Gornyi Zhurnal, (11-12), 95-97.

[14] Cherniaiev, O.V. (2017). Systematization of the hard rock non-metallic mineral deposits for improvement of their mining technologies. Naukovyi Visnyk Natsionalnoho Hirnychoho Universytetu, (5), 11-17.

[15] Rakhimov, V.R., \& Avakumov, A.L. (1997). Otrabotka mestorozhdeniy krutymi sloyami $\mathrm{v}$ usloviyakh otstavaniya vskryshnykh rabot. Gornyy Zhurnal, (7), 30-33.

[16] Anisimov, O.A. (2007). Formirovanie rabochego borta kar'yera krutonaklonnymi sloyami. Zbirnyk Naukovykh Prats NHU, (29), 18-22.

[17] Anisimov, O.O. (2018). Formuvannia bortiv hlybokoho kar'ieru krutymy sharamy. Zbirnyk Naukovykh Prats NHU, (55), 8-17.

[18] Anisimov, O.A. (2017). Parametry rabochykh bortov glubokikh kar'yerov pri formirovanii rabochei zony krutonaklonnymi sloyami. Zbirnyk Naukovykh Prats NHU, (52), 47-56.

[19] Anisimov, O.O. (2017). Doslidzhennia zminy kuta ukosu robochoho bortu kar'iera z vidpratsiuvanniam porid rozkryvu krutonakhylenymy sharamy. Kachestvo Mineralnogo Syr'ya, (4), 557-563.

[20] Anisimov, O.A. (2018). Tekhnologicheskie resheniya razmeshcheniya osnovnykh transportnykh kommunikatsiy pri formirovanii rabochey zony kar'yerov krutonaklonnymi sloyami. Zbirnyk Naukovykh Prats NHU, (54), 28-38.

[21] Anisimov, O.A. (2016). Mekhanizirovannye kompleksy v usloviyakh razrabotki krutopadayushchikh mestorozhdeniy krutonaklonnymi sloyami. Forum Hirnykiv, (2), 72-76.

[22] Anisimov, O.A. (2017). Issledovanie formirovaniya mekhanizirovannykh kompleksov i ikh vliyanie na shirinu krutonaklonnogo sloya pri otrabotke krutopadayushchikh mestorozhdeniy. Zbirnyk Naukovykh Prats NHU, (50), 26-32.

[23] Drizhenko, A.Yu., \& Anisimov, O.A. (2013). Upravlenie vyemkoyporodvskryshipri formirovanii vyrabotannogo prostranstva glubokikh kar'yerov pochvoustupnymi krutonaklonnymi sloyami. Forum Hirnykiv, (1), 168-172.

[24] Anistratov, Yu.I. (2005). Tekhnologicheskie potoki na kar'yerakh: Energeticheskaya teoriya otkrytykh gornykh rabot. Moskva, Rossiya: Globus, 304 s.

[25] Drizhenko, A.Yu., Kozenko, G.V., \& Rikus, A.O. (2009). Otkrytaya razrabotka zheleznykh rud Ukrainy: Sostoyanie i puti sovershenstvovaniya. Dnepropetrovsk, Ukraina: NGU, $452 \mathrm{~s}$.

[26] Drizhenko, A.Yu. (2011). Kar'yernye tekhnologicheskie gornotransportnye sistemy. Dnepropetrovsk, Ukraina: NGU, $542 \mathrm{~s}$.

[27] Dryzhenko, A.Yu. (2014). Vidkryti hirnychi roboty. Dnipropetrovsk, Ukraina: NHU, $590 \mathrm{~s}$.

[28] Evlanov, L.G. (1984). Teoriya i praktika prinyatiya resheniy. Moskva, Rossiya: Ekonomika, $176 \mathrm{~s}$.

[29] Zagubinoga, V.V., Panchenko, V.V., \& Erpert, A.M. (2013). Godovoe planirovanie gornykh rabot na zhelezorudnykh kar'yerakh: Strukturizatsiya prinyatiya resheniy. Forum Hirnykiv, (1), 145-151. 


\section{Календарне планування відкритої розробки крутопадаючих залізорудних родовищ крутопохилими шарами}

\section{В. Панченко, Б. Собко, В. Лотоус, Д. Вінівітін, В. Шабатура}

Мета. Створення методики ефективного календарного планування розробки крутопадаючих залізорудних родовищ крутопохилими шарами на основі виробничого досвіду кар'єру Полтавського ГЗК.

Методика. Для досягнення мети використано системний аналіз практики календарного планування відкритої розробки крутопадаючих родовищ крутопохилими шарами у кар'єрі Полтавського ГЗК і виконана структуризація процесу планування 3 позицій теорії прийняття рішень в умовах невизначеності.

Результати. Розроблено нову методику календарного планування відкритої розробки крутопадаючих залізорудних родовищ крутопохилими шарами. Запропонована методика представлена у змістовній (описовій) формі, яка $\epsilon$ обов'язковою (вихідною) для подальшого переходу до формалізації окремих стадій прийняття технологічних рішень в ході планування. Рекомендовано для підвищення ефективності календарного планування підготовку вихідних технологічних даних здійснювати у програмному комплексі K-MINE, а визначення економічних показників і контуру кар'єрів - у програмі Deswik.

Наукова новизна. Вперше для традиційних технологій відкритої розробки встановлено новий механізм цілеспрямованого просторово-часового регулювання конкретними обсягами виймання шляхом зміни часу "запуску" та інтенсивності відпрацювання шару, що дозволяє реалізувати кусочно-стабільну динаміку річних обсягів виймання. Механізм також дозволяє вирішувати зворотне завдання - визначати необхідні значення просторово-часових регульованих параметрів (часу “запуску” та інтенсивності відпрацювання шарів) для потрібної динаміки обсягів виймання руди і розкривних порід.

Практична значимість. Здійснено успішну апробацію запропонованої методики календарного планування відкритої розробки крутопадаючих залізорудних кар'єрів крутопохилими шарами при плануванні гірничих робіт у кар'єрі Полтавського ГЗК і підтверджена іï ефективність. В даний час вона є основним застосовуваним методичним забезпеченням календарного планування розробки крутопохилими шарами у розглянутому кар'єрі.

Ключові слова: крутопадаючі залізорудні родовища, відкрита розробка, крутопохилі шари, календарне планування

\section{Календарное планирование открытой разработки крутопадающих железорудных месторождений крутонаклонными слоями}

\section{В. Панченко, Б. Собко, В. Лотоус, Д. Винивитин, В. Шабатура}

Цель. Создание методики эффективного календарного планирования разработки крутопадающих железорудных месторождений крутонаклонными слоями на основе производственного опыта карьера Полтавского ГОК.

Методика. Для достижения цели использован системный анализ практики календарного планирования открытой разработки крутопадающих месторождений крутонаклонными слоями в карьере Полтавского ГОК и выполнена структуризация процесса планирования с позиций теории принятия решений в условиях неопределенностей.

Результаты. Разработана новая методика календарного планирования открытой разработки крутопадающих железорудных месторождений крутонаклонными слоями. Предложенная методика представлена в содержательной (описательной) форме, которая является обязательной (исходной) для последующего перехода к формализации отдельных стадий принятия технологических решений в ходе планирования. Рекомендовано для повышения эффективности календарного планирования подготовку исходных технологических данных производить в программном комплексе K-MINE, а определение экономических показателей и контура карьеров - в программе Deswik.

Научная новизна. Впервые для традиционных технологий открытой разработки установлен новый механизм целенаправленного пространственно-временного регулирования конкретными объемами выемки путем изменения времени “запуска" и интенсивности отработки слоя, что позволяет реализовать кусочно-стабильную динамику годовых объемов выемки. Механизм также позволяет решать обратную задачу - определять необходимые значения пространственно-временных регулируемых параметров (времени “запуска" и интенсивности отработки слоев) для необходимой динамики объемов выемки руды и вскрышных пород.

Практическая значимость. Осуществлена успешная апробации предложенной методики календарного планирования открытой разработки крутопадающих железорудных карьеров крутонаклонными слоями при планировании горных работ в карьере Полтавского ГОК и подтверждена ее эффективность. В настоящее время она является основным применяемым методическим обеспечением календарного планирования разработки крутонаклонными слоями в рассматриваемом карьере.

Ключевые слова: крутопадающие железорудные месторождения, открытая разработка, крутонаклонные слои, календарное планирование 